\title{
THE
}

\section{Sociological Review}

VOL. XIII. No. 4.

OCTOBER, 1921.

\section{MOUNTAIN, FOREST AND RIVER.}

Indeed one might work out a strong argument for the value of these districts of survival, on the ground that ancient survivals are often the real beginnings of fresh initiative.-Fleure.

ART, as in all matters of life, is a case of looking backward in order to look forward. The new ventures, the fresh ideas have, more frequently than we are apt to imagine, their inspiration in, not perhaps so much the works of some past ancient civilization, as in the conditions which created that civilization, conditions of place, work and folk, which in their original sense still obtain, and still influence and determine the avenue of new adventure. The following is an attempt to indicate how these resulted in the diverse architecture of the various countries of its origin.

Much that I have to say, has been said before. Geographical and social conditions, and their resultant effects on architecture, have been in some measure considered by most architectural writers; but, perhaps, what has not been so fully appreciated, is the fact that the earlier and more primitive conditions of life have for all times influenced all subsequent art, and will continue to exert such influence, throughout the ages.

It is more particularly with the comparisons afforded between the early civilizations of Mesopotamia and Egypt, the classic life of ancient Greece and Rome and the mediæval life of Northern Europe, with which I am now attempting to deal.

Greece and Italy are both mountainous lands with sunny slopes towards the temperate sea. They have from their position and the character of their soil afforded from early times settlements for man, giving him in exchange for moderate effort a sufficiency of material things, with leisure for the cultivation of the higher interests of life. These are the classic lands of olive, vine and corn. The history of early Mediterranean civilization, the story of the great human sea, has been such a constant theme of historians and writers, and is so well known that it is only proposed to touch on some of its outstanding features in this short sketch. 
In contradistinction, the great European plain which stretches from the British Isles and the Paris basin to the forests of Russia, including as it does the great Powers of modern Europe, may be described as the land of "Mediæval" or so-called "Gothic" culture. Throughout this plain, the dominant primeval covering was the damp temperate forest, and it is the conquest of this forest and its influence on the habits and imaginations of its conquerors, that has so profoundly influenced the history and arts of modern Europe.

It is with the contrast of these two zones, of the classic lands of the Mediterranean on the one hand with the great European plain on the other, and of the resultant buildings that their different civilizations produced, that we are now concerned.

In ancient Greece, the home of classic architecture, we have an abundance of limestone in the hills and mountains surrounding the Athenian plain, with the beautiful marble of Pentelicus near at hand, and that of Paros and Naxos, available a short distance across the sea. Now it was the abundance and availability of this limestone and marble that mainly determined the character and development of classic architecture. We might even go so far as to call it the architecture of the quarryman, in distinction and opposition to the architecture of the great European plain, which might be described as that of the woodman.

The use of large stones has been an important factor in classic building from the earliest examples. From the time when those mysterious Pelasgians built their gigantic walls round the Acropolis and elsewhere a love of large simple stones seems to have been an ineradicable characteristic of Greek and Roman builders.

In that ambitious project of Pisistratus, the temple of Zeus Olympius, which remained unfinished to the time of Hadrian : one of the drums of the columns of Piraic limestone (the largest extant Greek column known) is $7 \mathrm{ft}$. Io in. across. Those of the Parthenon of Pentelic marble are $6 \mathrm{ft} .3$ in. across at the bottom.

It is then quite obvious, after a very little reflection, that it was only the nearness of the quarries that made the use of such large stones practical. If they had had to be brought from great distances, the expense and difficulty of transport in those early days would have made the employment of them, for all except the most important of their buildings, an impossibility. Whereas we find them in pretty general use as far as the earlier buildings of the Motherland and the Western Colonies of Greece are concerned.

In the eastern colonies of Ionia a lighter form of column was used, though here too there is evidence of a liking for the large stone, as witness the columns of the temple of Diana at Ephesus, the capital of which may be seen at the British Museum. 
The history of Greek temple architecture is the slow evolution of two distinct types-the Doric and the Ionic-without any real change in variety, rather a gradual perfection of early prototypes, resulting in the crowning glories of the Parthenon and the Erectheum on the Acropolis at Athens in the 5th century B.c.

It is not proposed here to go into the much discussed question of the origin of these two types or to state whether they sprang from certain rock-cut tombs or from some earlier timber post construction.

The glory of Greek architecture is not concerned with its origin, but with what it became in the fulness of its harmonious completion. These Greek temple shapes are essentially the work of a mountain people, expressing as they do in every part repose, security and balance, wrought with loving care out of the hill or mountain on which they stand.

Contrast the long low lines of the Parthenon, having the stability of a hill top building with the aspiring wonder of Nôtre Dame or Amiens-the buildings of the plain. Not that we do not find the Gothic cathedrals on hills-as at Lincoln or Chartres, and classic temples on the plain-as the Theseum at Athens; but these examples do not invalidate the general argument, which is that the classic temple is peculiarly the work of a mountainous people, long used to the knowledge and limitations of stone, whilst the Gothic temples are the creation of the plainsman desirous of attaining height and elevation and working under the influence of that primeval forest which had exercised such influence on the early history of his race.

As I have already stated, the large stone and the square form of the structure is a characteristic of all classic buildings from Greek and Roman to Renaissance times; it resulted in a simplicity of outline and a directness of design.

This then was the architecture of the quarryman, the worker in stone, who from intimate knowledge and love of his material, was able to produce the wonder of the Parthenon. We know him under various names-as the rough hewer and excavator at the quarry; as the mason who dresses the more finished stone, and as the sculptor who adorns it and makes it precious with his ideas and fancies. Fundamentally, they are all one and the same, workers in stone; and if either of the higher grades, the mason or the sculptor, forget the origin of their material, forget the simple square outlines of the original block, their work will become debased, and whatever beauty they may achieve it will not be the beauty of the classic.

We know for a fact that many of the stones for the Parthenon were actually worked at the quarries, leaving the finishing touches 
only for the masons, who were to put them in position on the building. Consider with what exquisite care the drums of the columns were jointed; so finely that the completed columns, except to the closest scrutiny, gave an appearance of being formed of one single stone. And the ill-success of recent unfortunate attempts to restore some of the fallen columns is entirely due to the fact that owing to the edges of the flutings round the drums having been broken in their fall it has been impossible to give the re-erected columns that appearance of a single stone on which the success of the building as a whole so greatly depended. The result is singularly lifeless, as of a corpse galvanized into dreadful activity by means of some hidden agent, but lacking all the convincing vitality of the living flesh.

It must not be thought for a moment that the beauty of Greek buldings depended solely on fine masonry and large stones; indeed, in some of the more beautiful of the smaller temples the stones are comparatively small.

It was the whole life of these favoured mountainous and maritime people, with their ideals and aspirations, their religion and politics, that made these buildings possible. Their love of an outdoor life and their almost worshipful admiration of the human figure, resulted in that marvellous sculpture which has been the delight and despair of all succeeding ages. But it was the mountain that was, above all, the real determining factor of their architecture. It was the friendly barrier against the barbarian invader, the citadel of refuge, the kindly provider of the choicest materials for the habitations of people and gods. The dwellers in the Northern plains have rather a horror of the mountainto them it stands for something alien and terrible. Life for them has always been a more serious business, the result of prolonged and sustained fight with the forces of nature. First the forest, which had to be cleared and conquered, and then the climate and soil. To them the mountains stood for the sterile and unyielding ground which could give them no return for their labour, the heights from which descended the hillmen and the invader. But the fear of the mountain was remote and not like that of the forest, immediate and insistent. The one was an unknown and threatening stranger, the other a known and dreaded tyrant, demanding constant warfare and a never-ceasing vigilance.

Professor Fleure in his illuminating work, "Human Geography in Western Europe," describes the influence of the forest in these words :-

Man, occupying this zone, began in some parts as a shepherd on the heights, in others as a lake-dweller, but it needed immense effort before he could convert the forest into farm and corn land. 
There can be little doubt that the local folk lore, collected by the Grimms, for instance, is related to the clearing of the forest, the clash of grass landers and hillmen and forest hunters, the finding of nests of wild aboriginal folks in the forest depths.

War against the forest enforced co-operation, and the agricultural village community is, or has once been, characteristic of practically the whole forest zone, from the days when man moved valleywards, down to the time when the forest ceased to play a great part in every day life, because communications and the policing of the ways had developed.

As the mountain life in Greece together with the clear beautiful climate developed in the Greeks a love of openness and simplicity, and a hatred of mystery and uncertainty; so the northern forests left a legacy of fear and mystery, growing less as the forest receded, but colouring for all time the habits and thoughts of the peoples of Northern Europe.

But if the forest exacted hard work and sustained effort it also brought many good gifts to its inhabitants. The gifts of fuel and an abundance of timber for houses and ships.

It will be easily understood how the clearing of the forest developed a race of woodlanders and a knowledge and use of timber construction. Even to this day fine examples of timber and half-timber houses dating from the Middle Ages are common to England, France and Germany, as well as Norway, Sweden and Russia, houses characteristic of the forest zone, and not found in the stone and marble districts of the southern countries.

The position of France, with its window on the Mediterranean, made it the shortest and clearest route across the Continent from the south, along which flowed the more ancient civilizations northwards. France was particularly susceptible to all influences coming from the classic lands, so that we afterwards find her under the influence of the Benedictine builders, building that unrivalled series of cathedrals in the Paris basin; and at a still later time and whilst Italy was groaning under the Spanish domination, taking up the traditions of the Renaissance.

Owing to the geographical situation, France became at an early date the first cleared part of the temperate forest: " the place where all types mixed, the place where the wild men of the north learnt to revere the great memory of Rome."

After the withdrawal of the Romans and at the time when the French were developing what is called the Romanesque style, they had at first no other thought than to imitate the square barrel vaulting of their imperial teachers.

Every effort was made to vault the churches in a way as nearly as possible like those chambers of ancient Rome baths and other 
buildings which in the ninth and again in the eleventh century were somewhat familiar to the inhabitants. As, however, the Roman system of building with the solid block of mortar masonry, could hardly be achieved by these poor and half-organized communities they undertook the bold task of doing what the Romans had never done, and building groined vaults with separate visible stones. These were not indeed what we should call squared rubble or dressed rubble, no piece being larger than a man could carry on his shoulder or otherwise up a ladder, and then put into place without the aid of machinery.

We here see the instinctive turning of the woodlander to ideas of timber construction; nothing is easier, nor indeed more common, than the use of wood ribs with panelling. So that immediately he has to attempt a new and difficult problem he falls back on the old traditional method with which he is familiar.

Ruskin, in his "Stones of Venice," describes the transition from wood to stone of the early Gothic churches :-

The Lombard architecture represents, as I said, the whole of that of the northern barbaric nations. And this, I believe, was, at first an imitation in wood of the Christian Roman Churches, or basilicas. Without staying to examine the whole structure of a basilica, the reader will easily understand thus much of it: that it had a nave and two aisles, the nave much higher than the aisles that the nave was separated from the aisles by two rows of shafts, which supported, above, large spaces of flat or dead wall, rising above the aisles, and forming the upper part of the nave, now called the clerestory, which had a gabled wooden roof. These high dead walls were, in Roman work, built of stone; but in the wooden work of the north, they must necessarily have been made of horizontal boards or timbers attached to uprights on the top of the nave pillars, which were themselves also of wood. Now, these uprights were necessarily thicker than the rest of the timbers, and formed vertical square pilasters above the nave piers. As Christianity extended and civilization increased, these wooden structures were changed into stone; but they were literally petrified, retaining the form which had been made necessary by their being of wood. The upright pilaster above the nave pier remains in the stone edifice, and is the first form of the great distinctive feature of northern architecture. In that form the Lombards brought it into Italy in the seventh century, and it remains to this day in St. Ambrogio of Milan and St. Michele of Pavia.

When the vaulting shaft was introduced in the clerestory walls additional members were added for its support of the nave piers.

Perhaps two or three pine trunks, used for a single pillar, gave the first idea of the grouped shaft.

We have now all the factors which produced those marvellous cathedrals in France, on the Rhine border and in this country; the great artistic achievement of the Middle Ages.

First, the great European plain with its traditions of forest lore and wood-craft, open to the passage of the Mediterranean people 
through France; secondly, the difficulty of imitating Roman construction with small stones, the use of which was necessitated by the distance of the mountains and quarries from the central portion of the Paris basin where these efforts were first made, and the difficulty of carrying such stones with the transport at that time available; and, thirdly, the application of timber methods of construction to stone. It is not without reason that writers on mediæval architecture have dwelt on the analogy of the great cathedral vaults and arcades with the forest avenues and the branching trees.

*The Gothic church plainly originated in a rude adaptation of the forest trees with all their boughs to a festal or solemn arcade, as the bands above the cleft pillars still indicate the green withes that tied them. No one can walk in a road cut through pine woods, without being struck with the architectural appearance of the grove, especially in winter, when the bareness of all other trees show the low arch of the Saxons. In the woods in a winter afternoon one will see as readily the origin of the stained glass window with which the Gothic cathedrals are adorned, in the colours of the western sky seen through the bare and crossing branches of the forest. Nor can any lover of nature enter the old piles of Oxford and the English cathedrals without feeling that the forest overpowered the mind of the builder, and that his chisel, his saw, and plane still reproduced its ferns, its spikes of flowers, its locust, its pine, its oak, its fir, its spruce.

As mediæval building develops through the Decorated and Flamboyant periods, this analogy becomes more and more striking. Under the guidance of the chief stone workers, who became rather carvers than sculptors, is developed crocket, trefoil and cusp, the lines of forest growth become more and more pronounced, the use of rib panelling or vaulting with the arch and buttress are carried to such daring conclusions that any further advance is impossible; and with the passing away of that religious inspiration which was responsible for those wondrous and beautiful fanes, there passes away also those mighty master builders who, in the midst of their fertile plains, sent their aspiring edifices flaming up to God.

So far, I have dealt only with a comparison between the origins of Classic and Gothic work, but it might be instructive and interesting to turn to the earlier work of Mesopotamia and Egypt, and to enquire whether the same underlying conditions of place, work and folk determined the style and character of the architecture.

The geographical conditions of Mesopotamia and Egypt are very similar ; both countries depend for their fertility on the regular inundations of their rivers.

Mesopotomia, which at the present time looms so largely in the political foreground, is a large tract of land lying between the two historic rivers of the Euphrates and the Tigris.

*Emerson's Essay on History. 
In early times this land was developed by a wonderful system of irrigation, traces of which can still be found throughout the district. The neglect of the waterworks following the invasion of the country by the nomadic and unagricultural Arab led to the reversion of the whole land to desert.

But it is with the earlier civilization that we are now concerned, with the primitive agricultural life, which has ever tended to the concentration of wealth in centres, and here produced the historic city of Babylon.

The whole of the southern portion of Mesopotomia is quite flat, the northern part being bounded by a series of low limestone hills, so that building materials were limited. There was very little timber; the only available stone was the limestone in the north, but there was an abundance of clay, and, as a consequence, the architecture of Mesopotamia was essentially a clay architecture.

It was the country round the deltas of the rivers that was the first to be cultivated, and it was here that the first cities sprang up and the character of Babylonian and Assyrian civilization determined.

It was the mud of the river deltas that formed the first building material, and it was the primitive agriculturalist working on this mud that determined the character of the stone architecture of Assyria; for in the same way, that the northern nations of Europe translated their timber buildings into the more permanent stone of the Middle Ages, so did the Assyrians translate the clay forms of their neighbours into the stone palaces of Ninevah.

The brick used would, for the most part, appear to have been a sun-dried brick used in great masses and protected with an outer casing of hard burnt bricks. Travellers from Mesopotamia inform me that the burnt bricks exist to-day as hard as iron, whilst the sun. dried bricks have crumbled into shapeless heaps.

Conjectural restorations of Babylonian buildings show us enormously solid structures with tiny apertures-roofs, walls, stairs, or sloping ways, all built of clay-such was the river architecture of Babylon and Mesopotamia.

Clay, as the sculptors will tell us, is a wonderful medium for modelling in, but to make such modelled work permanent it must be burnt in the form of terra-cotta or translated into stone.

The character of a purely clay decoration would, particularly in primitive buildings, be of very low relief.

We can form a very good idea of what Babylonian ornament must have been from that wonderful series of Assyrian bas-reliefs that we have at the British Museum. If we examine this series 
carefully we shall discover the essentially clay character of their prototypes. The very low relief, the carefully rounded surfaces, the conventional treatment of face, hair and drapery, all witness to generations of clay workers, who must have followed on identical lines for centuries, the slowly changing conservatism of a primitive agricultural people. Nothing else would account for the exquisite finish and the extraordinary vigour of these severely conventionalized panels.

It may have been that the earlier Babylonian builders had slabs of this precious limestone brought down by river, and that they treated it as a modern painter would treat a piece of canvas as the background and material for his picture.

Colour must, of course, have entered largely into the scheme of decoration of all Mesopotamia buildings; but what we are chiefly concerned with now is the consideration of how the clay of the deltas became translated into the limestone of the northern hills, and to realize the essential difference that such a translation from such an origin would mean as compared with the quarryman's architecture of Greece and Rome, or the transmuted timber to stone architecture of Northern Europe.

I have said that the geographical conditions of Mesopotamia and Egypt have much in common, but there is one very great and important difference. The architecture of Egypt is also a river architecture, owing its origin to mud and reeds; but it was an architecture transmuted from clay to granite, and it was the near presence of this granite in abundant quantities that made the vital difference. Here, as in Mesopotamia, civilization started in the deltas, and here again clay was the immediate and general material for building. It will be remembered that one of the complaints of the Hebrews before they made the great trek was that they had to make bricks without straw, so that the sun-dried or soft brick was also an essential of early Egyptian building.

The valley of the Nile, nowhere more than some 30 miles wide, is to this day one of the most fertile of places, and in ancient times, under a compact and intensely industrious population, it must indeed have been one of the wealth-producing centres of the world.

This valley, bounded on either side by mountains of granite, forming the outer guards between the fertile corn lands and the desert, was destined to play a great part in the history of the human race. Mr. March Phillips in his book, "Man and his Works," gives a most interesting description of early Egyptian civilization, the life of a hard-working and conservative slave population of agriculturalists, whose sole existence revolved round 
the river Nile, and how this great river, with its regular inundations, fertilized their valley, and determined the whole tenor of their lives. It gave them their bread, their laws and their religion.

The Egyptian temples, far more than the Greek, evidence the slow changing, or rather unchanging, habits of their builders. For thousands of years the Egyptian temple was evolved with scarcely any radical changes, each and every building showing unmistakable traces of its clay origin.

The battering walls so characteristic of clay, so wasteful a use of granite, those lintels of enormous depth and columns of tremendous girth, all bear witness to the influence of a cheaper and more easily worked material. With clay one can take no risks, particularly with clay used in the form of sun-dried bricks; there must be a large factor of safety everywhere, there can be no nice calculations as to load and resistance-lintel, column and wall must be generous and ample.

So we have your essential clay worker building in granite, using lintel, column and wall of the same generous amplitude as if he had been building of clay; in granite, the hardest, strongest and most costly to work of all building stones.

Only a nation that for thousands of years had followed the same unchanging round year in and year out, only a nation of slaves and agricultural slaves at that, could have created these gigantic clay monuments of granite.

Without imagination, inspired by the one great central fact of their lives and their civilization, the mighty life-giving river, these early builders have given us a series of monuments which make all the more imaginative of works of later and more adventurous people appear slight and trivial. It was the wonderful juxtaposition of clay and granite, the softest and the hardest of all building materials, which in the hands of the most conservative race the world has known, produced that series of mighty buildings which we know as Egyptian architecture.

Both in Egypt and Mesopotamia the architecture was the architecture of the river and the plain, and in both countries we find evidence of the perpetual desire of the plainsman to achieve height-the dramatic contract between art and nature.

In Mesopotamia there would appear to have been great towers built with diminishing storeys, each one reached in succession by a continuous road or inclined slope. In Egypt we have the eternal pyramids and the granite obelisk, the latter perhaps the only essentially granite monument evolved by the Egyptians.

This, probably, is the only comparison that can be made between the works of these ancient eastern builders and the cathedrals 
and churches of the Middle Ages, in all other respects so utterly dissimilar. The clay mounds of the dweller by the river, the soaring lines of the woodlander, both contrasting with the long, low buildings of the quarryman of the mountains.

Stanley C. Ramsey.

\section{Labour as an International Problem. Edited by John Solano. Macmillan,} 1920.

The British Labour Delegation to the Peace Conference made a proposal that instead of centering attention solely on any specific claims of labour which might be inserted in the Peace Treaty, there should be erected an annually recurring International Labour Parliament and an International Labour Office, which should so secure, not one single Labour Charter, but a developing series. This will perhaps in the future be regarded as the most fruitful suggestion embodied in the Peace Treaty. The Conference is not a legislative body in the usual sense; its decrees are not binding as such. The power of the International Parliament consists in its right to secure the submission of its laws to the legislature or other competent authority of the participating states, and its recommendations must be brought within a given time to the attention of Parliament or Congress or whatever law-making body the country may possess (Shotwell, p. 53). Once ratified by the legislature, the recommendations are binding on the country concerned, and the executive is responsible for their enforcement.

The functions of the International Labour Office are of great importance, as it has the duty of investigating the technical problems involved in the proposals of social reform which are to be brought before the Conference; and it also assists in securing the observance of the conventions adopted, and in adapting these to the needs of various countries; and deals with complaints of non-observance. A further important task of the I.L.O. consists in the collection and distribution of information on all subjects relating to the international adjustment of industrial questions.

This book should be a powerful aid in the education of public opinion on a subject the importance of which is only just beginning to be recognized. Different sections of the subject are treated by different experts, and while all, or nearly all, are good, we think a special interest will be found in the papers by Mr. Oka, Miss Sanger, Mr. Albert Thomas and Mr. Shotwell.

An index is unfortunately missing.

B.L.H.

Labour and Industry : A series of lectures by Percy Alden, J. M. Baillie, Gerald Bellhouse, J. R. Clynes, G. D. H. Cole, Sir Malcolm Delevigne, Sir D. L. Drummond Fraser, F. W. Goldstone, Percy J. Pybus, R. H. Tawney, Miss E. B. Voysey, J. H. Whitley. Longmans, Green and Co., University Press, Manchester, 1920.

This book is a good summary of contemporary thought on the civics of industry. Amongst the most interesting subjects dealt with are works committees, democratic management of industry, welfare work, education, safety first, and the output and reward of labour. 